\title{
Unraveling intractable water conflicts: the entanglement of science and politics in decision-making on large hydraulic infrastructure
}

\author{
Jonatan Godinez-Madrigal $^{1,2}$, Nora Van Cauwenbergh ${ }^{1}$, and Pieter van der Zaag ${ }^{1,2}$ \\ ${ }^{1}$ Department of Land and Water Management, IHE Delft, Delft, the Netherlands \\ ${ }^{2}$ Water Management Department, TU Delft, Delft, the Netherlands
}

Correspondence: Jonatan Godinez-Madrigal (j.godinezmadrigal@gmail.com)

Received: 24 February 2020 - Discussion started: 10 March 2020

Revised: 13 August 2020 - Accepted: 25 August 2020 - Published: 19 October 2020

\begin{abstract}
The development of large infrastructure to address the water challenges of cities around the world can be a financial and social burden for many cities because of the hidden costs these works entail and social conflicts they often trigger. When conflicts erupt, science is often expected to play a key role in informing policymakers and social actors to clarify controversies surrounding policy responses to water scarcity. However, managing conflicts is a sociopolitical process, and often quantitative models are used as an attempt to depoliticize such processes, conveying the idea that optimal solutions can be objectively identified despite the many perspectives and interests at play. This raises the question as to whether science depoliticizes water conflicts or whether instead conflicts politicize science-policy processes. We use the Zapotillo dam and water transfer project in Mexico to analyze the role of science-policy processes in water conflicts. The Zapotillo project aims at augmenting urban water supply to Guadalajara and León, two large cities in western Mexico, but a social and legal conflict has stalled the project until today. To analyze the conflict and how stakeholders make sense of it, we interviewed the most relevant actors and studied the negotiations between different interest groups through participant observation. To examine the role of science-policy processes in the conflict, we mobilized concepts of epistemic uncertainty and ambiguity and analyzed the design and use of water resources models produced by key actors aiming to resolve the conflict. While the use of models is a proven method to construct future scenarios and test different strategies, the parameterization of scenarios and their results are influenced by the knowledge and/or interests of actors behind the model. We found that in the Zapotillo case, scenarios reflected the interests and strategies of actors on one side
\end{abstract}

of the conflict, resulting in increased distrust of the opposing actors. We conclude that the dilemma of achieving urban water security through investing in either large infrastructure (supply augmentation) or alternative strategies (demand-side management) cannot be resolved if some key interested parties have not been involved in the scientific processes framing the problem and solution space.

\section{Introduction}

Urban water systems around the world are experiencing various urgent challenges to address water scarcity, flooding, and bad water quality (Zevenbergen et al., 2008; McDonald et al., 2014). The scope of these challenges is such that individual scientific disciplines and traditional approaches fall short of addressing them in a thorough manner to unequivocally inform policy (Funtowicz and Ravetz, 1994; Larsen et al., 2016; Hoekstra et al., 2018). Any solution to the challenges facing urban water systems will have manifold uncertainties in projected costs, benefits, and risks, and this is especially true when large infrastructures are considered (see, e.g., Flyvbjerg, 2009, and Crow-Miller et al., 2017, for a general description of the contentious process of cost-benefit assessments of large infrastructures; and for specific cases, see Berkoff, 2003, for China; Hommes et al., 2016, for Turkey; Hommes and Boelens, 2017, for Peru; and Molle and Floch, 2008, for Thailand). How the perceived costs, benefits, and risks are shared among the stakeholders is one of the causes of water conflicts (Delli Priscoli and Wolf, 2009).

Since these conflicts are politically perilous situations, many policymakers seek specialized scientific knowledge 
that is perceived as neutral and unbiased to serve as the basis of making difficult decisions over controversial issues (Schneider and Ingram, 1997). In recent years, political ecology literature has acknowledged that this specialized scientific knowledge can act as a form of stealth advocacy in politically charged socio-environmental problems (e.g., Pielke, 2007; Budds, 2009; and Sanz et al., 2019, for groundwater overexploitation and allocation; and Godinez-Madrigal et al., 2019 , for water scarcity and surface water allocation). However, literature related to science-policy processes in contexts of intractable conflict due to large infrastructure development is scarce.

This paper has two objectives: (1) to identify the causes of failure in science-policy processes to solve intractable conflicts and promote well-informed water management solutions and (2) to explore the multiple influences in the production of water knowledge in a context of conflict and its political use by actors. We contribute to the literature on sciencepolicy processes by analyzing the conflict over the Zapotillo dam and water transfer project, perhaps the most politically charged water conflict in Mexico in recent years. This case is of special relevance due to what is at stake: the water supply for the two most important cities in western Mexico, the economic importance of its semi-arid donor basin, and the possible displacement of three communities lying in the reservoir's area. Furthermore, the conflict can be considered intractable, given its length (it started more than 15 years ago) and that is still largely unresolved due to the intransigent positions of the stakeholders (Putnam and Wondolleck, 2003; Pacheco-Vega, 2014). The focus of this paper is the scientific knowledge produced through a water resources model developed by an independent international team of experts convened by UNOPS (United Nations Office for Project Services), hereafter referred to as the UNOPS team, as a means to clarify controversies, fill gaps in knowledge, and depoliticize the Zapotillo conflict. We demonstrate how the process of scientific production, in spite of its intended neutrality, favored the Zapotillo project, ignored alternatives proposed by the dam-affected stakeholders based on demand management strategies in the recipient cities, and improperly managed core uncertainties related to climate change and future water demand.

The paper is structured as follows. The first section analyzes the literature on science-policy processes in relation to epistemic uncertainties and controversies in water conflicts. We then describe the study area and the methods used to analyze the conflict. Subsequently, in the Results section, we first describe the trajectory of the regions that would benefit from the Zapotillo project. We then describe the main knowledge uncertainties and controversies that articulate the positions and frames of the actors in conflict. Subsequently we analyze the scientific products that were developed to support decision-making in the conflict. Finally, we discuss the theoretical contributions of the case to the literature of the role of science-policy processes in water conflicts.

\section{Science-policy processes and water conflicts}

\subsection{Uncertainties and ambiguity in science-policy processes}

Effective science-policy processes in water management are those where water knowledge informs decision makers as to what are the most appropriate solutions to water challenges and what is likely to happen if nothing is done (Karl et al., 2007). However, Funtowicz and Ravetz (1994) have argued that complex socio-environmental issues (e.g., climate change) are confronted by uncertainties, ethical complexities, and policy riddles regarding societal values, from which no clear-cut policies can be concluded.

Uncertainties consist not only of matters of lack of precision and accuracy in the data being analyzed, but also of epistemic uncertainties, related to the functioning of a given system (Funtowicz and Ravetz, 1994; Di Baldassarre et al., 2016; Cabello et al., 2018), and of ambiguity, understood as the "simultaneous presence of multiple valid and, sometimes, conflicting ways of framing a problem" (Brugnach and Ingram, 2012). Scientists cannot address these levels of uncertainty by simply improving their techniques or computational prowess (Di Baldassarre et al., 2016). Epistemic uncertainties and ambiguity are entangled with controversies of what the real problem is and how to frame the solutions in the political arena between actors with different interests (Gray, 2003; Cabello et al., 2018).

When facing epistemic uncertainties in a complex socioenvironmental problem, stakeholders stand on unexplored territory; even scientists face an ambiguous path in deciding which methodologies to use and how to interpret the phenomena (i.e., Melsen et al., 2018, and Srinivasan et al., 2018; see also Brugnach and Pahl-Wostl, 2008). Boelens et al. (2019) noted the relation of knowledge and power asymmetry between stakeholders in the context of large infrastructural schemes. Such asymmetry is characterized by hegemonic discourses that privilege technical knowledge as being infallible while other kinds of knowledge are disregarded to understand a socio-environmental problem (Schneider and Ingram, 1997; Wesselink et al., 2013). This may result in what Boelens et al. (2019) denominate "the manufacture of ignorance", understood as the process of cherry-picking facts and knowledge to further one's position while discrediting ex ante competing knowledge without a thorough debate (see also Flyvbjerg, 2009, and Moore et al., 2018). In the case of large infrastructures, governments undertake this process often by invoking scientific evidence (Brugnach et al., 2011), which is often presented acritically by downplaying the inherent risks and uncertainties (Flyvbjerg, 2009) and by presenting it as the only valid frame to understand socioenvironmental problems.

When science-policy debates ignore intrinsic epistemic uncertainties and ambiguity, it is expected that uncertainty is present in their scientific recommendations to policy (Fun- 
towicz and Ravetz, 1994), which makes such recommendations dubious or at least contestable. Alternatively, Pielke (2007, p. 17) proposed that the role of scientists in issues of high uncertainties and politicization should be that of "honest broker of policy alternatives", consisting of expanding the scope of alternatives to decision makers. Moreover, epistemic uncertainties and ambiguity can be made manageable through bottom-up approaches ${ }^{1}$, consisting of the inclusion of local stakeholders, their knowledge, problem framing, and alternative solutions in the policy debates (for a general description, see Brugnach et al., 2011, and for hydrological risk management, see Lane et al., 2011, and Blöschl et al., 2013). Nevertheless, public participation in socio-environmental decisions is a political decision often aimed at improving the acceptability and legitimization of policies (Newig, 2007) rather than reducing epistemic uncertainty and handling ambiguity (Blomquist and Schlager, 2005; Brugnach and Ingram, 2012). In such situations the underlying causes for conflict remain unaddressed.

\subsection{Water conflicts and co-production of knowledge}

Water conflicts emerge for many reasons, but we will explore those that emerge from the imposition of large infrastructural projects. These projects may produce many benefits but also socio-environmental costs and risks that are unevenly distributed between stakeholders. An example is the apparent urgency to implement supply augmentation and reallocation solutions to guarantee water supply to large cities. These solutions may hamper due processes of transparency, public participation, and the rights of other water users and stakeholders. The absence of these processes may create social conflicts (Barraqué and Zandaryaa, 2011; Roa-García, 2014), which are defined as "two or more entities, one or more of which perceives a goal as being blocked by another entity, and power being exerted to overcome the perceived blockage" (Frey, 1993, cited in Delli Priscoli and Wolf, 2009). Thus, water conflicts may block such supply augmentation projects from alleviating water scarcity while no alternative solutions are implemented. In doing so, actors in conflict may worsen the system as a whole (Madani, 2010), aggravating the social conditions by rationing water and deteriorating hydrological conditions by further depleting available water reserves like aquifers or dams.

When these conflicts are prolonged in time, the positions of the actors in conflict tend to harden, and the conflict may become intractable with small chances for a negotiated solution (Putnam and Wondolleck, 2003). Intractable conflicts are often also characterized by ambiguity, in which actors

\footnotetext{
${ }^{1}$ The difference between a top-down and a bottom-up approach is that the first focuses on highly technical assessments, while the second on the communities' vulnerabilities, making the latter more robust to a changing and unpredictable climate, no matter how low the probabilities of the occurrence of any event (Blöschl et al., 2013).
}

with different systems of knowledge (engineers, communities, policymakers, etc.) perceive the problem with different frames as well as its possible solutions (e.g., Table 1 presents the multiple frames of the actors in the Zapotillo conflict). A diversity of frames is possible since water problems are often unstructured and riddled by uncertainties in information and cause-effect relationships (Islam and Susskind, 2018). Even within stakeholder groups, stakeholders can make sense of the conflict using different frames (Brummans et al., 2008). Politicians typically expect scientists to contribute to unraveling what the problem is and to offer solutions supported by all actors (Schneider and Ingram, 1997). However, studies have identified political biases in allegedly neutral scientific studies (i.e., Budds, 2009; Milman and Ray, 2011; Fernandez, 2014; Sanz et al., 2019; Godinez-Madrigal et al., 2019), which have lately discredited science as a fair knowledge creator in some controversial large infrastructural water projects around the world (Boelens et al., 2019). Due to this situation, among others, more attention has been given to include stakeholders in research and decision-making (Armitage et al., 2015; Krueger et al., 2016).

Specialized literature provides some consistent recommendations regarding knowledge in contexts of conflict and a diversity of values in socio-environmental problems. Gupta and van der Zaag (2008) recommend considering five principles based on feasibility, sustainability, the consideration of alternatives, good governance, and the respect of rights and needs before undertaking large infrastructural schemes. Funtowicz and Ravetz (1994), Van Cauwenbergh (2008), Islam and Susskind (2018), Armitage et al. (2015), Dunn et al. (2017), and Norström et al. (2020) argue that since no expertise or discipline can claim to have the monopoly of wisdom in complex socio-environmental issues, the problem definition and possible solutions need to include local and nontechnical knowledge, therefore engaging in co-production of knowledge. This approach even provides the advantage of designing more robust and resilient solutions (Blöschl et al., 2013). This does not belittle scientific studies but changes their role to become boundary objects, which cannot illuminate stakeholders' decision-making but rather elicit new relationships and innovative solutions among the different systems of knowledge and frames present in all stakeholders (Lejano and Ingram, 2009). True knowledge controversies have the potential to be generative events in the sense that they open the ontological question of what is reality and how it is framed and redefine it in, hopefully, better terms (Callon, 1998; Latour, 2004; Whatmore, 2009).

However, little attention has been paid to science-policy processes in cases of intractable water conflicts based on the development of large infrastructures to solve urgent water problems. The next sections present the historical context of the conflict over the Zapotillo water transfer project in Mexico and analyze the knowledge controversies around the conflict and the scientific products developed by a team of experts fielded by UNOPS and by Conagua (the federal water 
Table 1. Main controversies and frames on the coupled human-water system of the regions and the Zapotillo project (ZP).

\begin{tabular}{|c|c|c|}
\hline General controversies & Specific controversies & Frames \\
\hline Recipient basins: policies for urban water security & $\begin{array}{l}\text { - the urgency to apply supply augmentation policies to } \\
\text { achieve water security } \\
\text { - replacing supply-side policies for demand manage- } \\
\text { ment policies and small-scale infrastructure: reducing } \\
\text { physical losses in the network and implementing rain- } \\
\text { water harvesting } \\
\text { - financial burden because of increasing unexpected } \\
\text { costs of large infrastructure } \\
\text { - alternative, in-basin water sources for León and } \\
\text { Guadalajara } \\
\text { - sectoral water transfers to reduce groundwater over- } \\
\text { exploitation }\end{array}$ & $\begin{array}{l}\text { - actors in favor of ZP: alternatives are un- } \\
\text { realistic; ZP is the only feasible solution to } \\
\text { achieve water security } \\
\text { - actors against ZP: alternatives exist and } \\
\text { can be cheaper, more sustainable, and more } \\
\text { socially just than ZP }\end{array}$ \\
\hline Negative consequences for the donor basin & $\begin{array}{l}\text { - dam's height in relation to the resettlement of the three } \\
\text { communities and the water allocation commitments to } \\
\text { León and Guadalajara } \\
\text { - overestimation of surface runoff in the Verde River } \\
\text { basin } \\
\text { - future water scarcity due to droughts and climate } \\
\text { change in the Verde River basin } \\
\text { - underestimated official water abstractions in the Verde } \\
\text { River basin } \\
\text { - regional socioeconomic dynamic is growing, as well } \\
\text { as water demand in the Verde River basin } \\
\text { - current groundwater overexploitation will increase in } \\
\text { the future } \\
\text { - the human rights of Temacapulín should be respected }\end{array}$ & $\begin{array}{l}\text { - actors in favor of ZP: there is enough wa- } \\
\text { ter in the donor basin for all existing and fu- } \\
\text { ture users; and a dam with a height of } 105 \mathrm{~m} \\
\text { is the best and most efficient solution that } \\
\text { benefits a great majority despite the social } \\
\text { costs of relocating Temacapulín } \\
\text { - only a dam with a height of } 60 \mathrm{~m} \text { is so- } \\
\text { cially feasible, since human rights are not } \\
\text { negotiable } \\
\text { - actors against ZP: there is currently not } \\
\text { enough water in the donor basin, and a wa- } \\
\text { ter transfer will have enduring negative ef- } \\
\text { fects for the region }\end{array}$ \\
\hline
\end{tabular}

authority) to solve the conflict and generate acceptance and legitimacy for the project.

\section{Case study and methods}

\subsection{Study areas}

Since the Zapotillo project entails the water transfer from the Verde River basin in the northeast of Jalisco to two cities located outside of the boundaries of the basin, three different regions constitute the area of interest of this study. Figure 1 shows the two recipient cities of the projected water transfer, Guadalajara and León, and the contiguous donor basin, the Verde River basin. Currently, Guadalajara has more than 4.5 million people and is the capital of the state of Jalisco. León has a population of around 1.5 million people and is the most populous and economically most important city of the state of Guanajuato ${ }^{2}$. The Verde River basin is a sub-basin of the Lerma-Santiago-Pacífico basin and discharges its water to the Santiago River located northwest of Guadalajara. The area of this sub-basin is around $21000 \mathrm{~km}^{2}$ large and is mainly located in the state of Jalisco (55\%). The sub-basin is considered as being semi-arid in the north, with an average precipitation of around $360 \mathrm{~mm} \mathrm{yr}^{-1}$, and subtropical in the south, with an average precipitation of $900 \mathrm{~mm} \mathrm{yr}^{-1}$. The average temperature varies between 11 and $18^{\circ} \mathrm{C}$ in winter and

\footnotetext{
${ }^{2}$ For further information on Guadalajara and León, consult the Supplement.
}

17 and $25^{\circ} \mathrm{C}$ in summer, and the average potential evaporation in the basin is around $1550 \mathrm{~mm} \mathrm{yr}^{-1}$ (UNOPS, 2017a). The basin is home to around 2 million people, of which almost half inhabit the region of Los Altos, located in the part of the basin that belongs to the state of Jalisco. The northern part of the basin, located in the state of Aguascalientes, is characterized by a developed industrial sector, while Los Altos is characterized by a vibrant primary sector of the economy, contributing to the production of around $20 \%$ of the total animal protein produce of the country (Ochoa-García et al., 2014).

\subsection{Methods}

To understand the science-policy processes in the context of an intractable conflict, we adopted an interdisciplinary method to comprehensively analyze the technical as well as the social issues that are central to the conflict. The first author spent 5 months before the public release of the report by the UNOPS team in Guadalajara in 2017 and 1 month after. He conducted 22 in-depth, semi-structured interviews with most of the key actors of the conflict: members of Jalisco's government, national and state water authorities, NGOs, scholars, the Citizens' Water Observatory (hereafter referred to as the Observatory), and representatives of the communities affected by the dam. Since the hotspot of the conflict was located in Jalisco, we decided to focus on Jalisco instead of Guanajuato, although we also collected information on Guanajuato through many actors in Jalisco that 


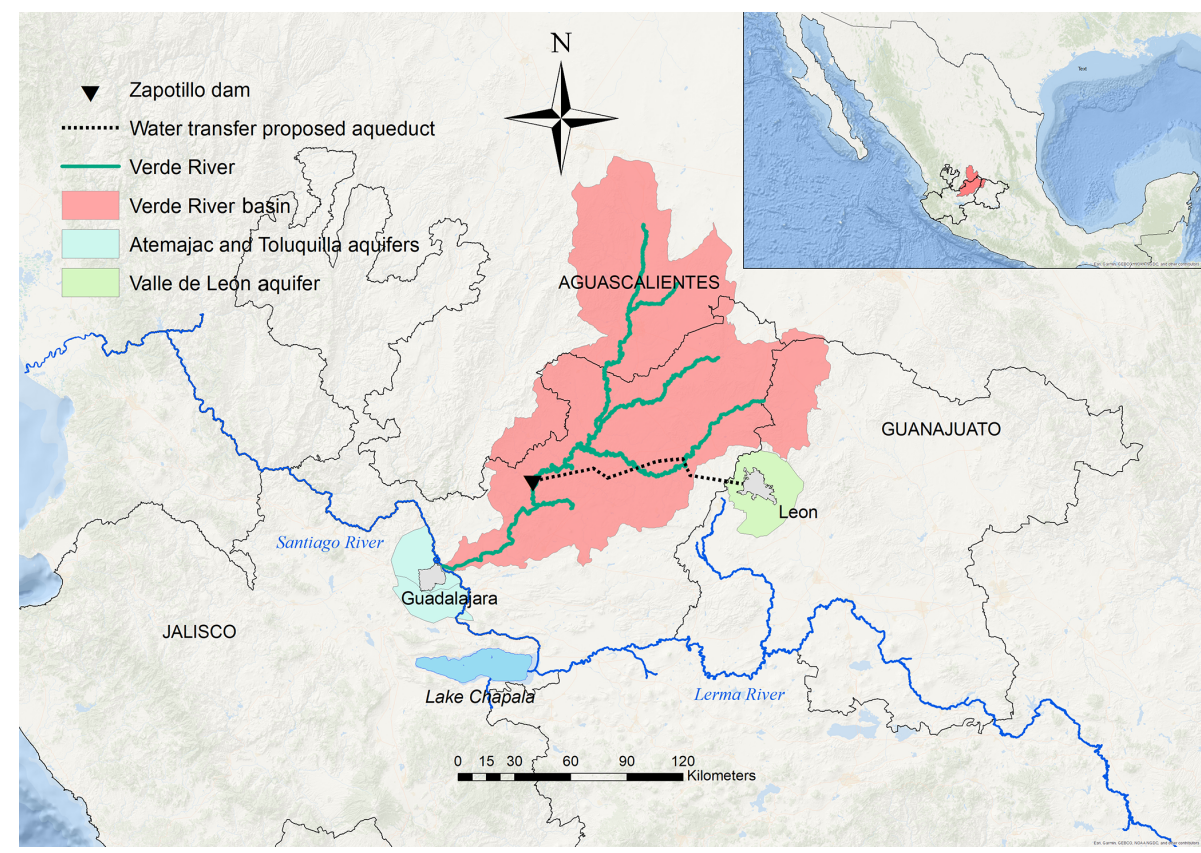

Figure 1. Map of the Verde River basin and main cities (source of GIS layers: (C) 2018 Conagua and @ 2019 Esri, Garmin, GEBCO, NOAA NGDC, and other contributors).

had close contact with key stakeholders in Guanajuato and through public statements and official documents of the local water utility and state water authorities. The semi-structured interviews consisted of exploring three main themes: the root causes of the problem and the conflict, what the sources of controversy in the conflict were, and what the preferred solutions to the conflict and the water scarcity problem would be. The interviews also served to identify the position and interests of the actors in the conflict according to Fisher et al. (2000) that in turn allowed for differentiation of the stakeholders following Reed at al. (2009). Due to the delicate nature of the situation, all interviewees remain anonymous, and not all interviews could be recorded; in such cases we relied on field notes taken immediately after the interview. The interviews that were recorded were transcribed. We analyzed the interview transcripts and field notes to extract the summarized viewpoints of the stakeholders, which are described in Table 1. We then conducted participant observation during five key meetings of the Observatory and Jalisco's government to analyze the discourses, knowledge claims, and main controversies on the coupled human-water system of the region. This allowed us to identify controversies and link the position of actors in the conflict to knowledge frames. Immediately after the presentation of results from the study by the UNOPS team, we conducted informal interviews with most of the key actors that were present to chronicle in our field notes their reactions to and opinions on the outcome of the study.

Afterwards, we requested from Jalisco's government the full water resources model that the UNOPS team developed; we received it by the end of 2017. The model was developed using the Water Evaluation and Planning System (WEAP21) software (see Supplement for a detailed description of the model) and contained the five scenarios that the UNOPS team used to test the viability of the Zapotillo dam project to reliably allocate water until the year 2069 (Fig. 2). The five scenarios switched parameters under different reservoir storage volumes (at dam heights of 80 and $105 \mathrm{~m}$ ), different water allocation volumes to Guadalajara, León, and the urban localities within the Verde River basin (three aggregated flows of water were considered: $8.6,4.8$, and $7.5 \mathrm{~m}^{3} \mathrm{~s}^{-1}$; Fig. 2 disaggregates these flows to the three users), changes in water availability related to climate change (RCP8.5 or no climate change), and changes in agricultural water demand in the donor basin (static water demand since the year 2018 or expected water demand in the year 2030).

The UNOPS team recommended decision makers that the best possible configuration of the Zapotillo project was that of scenario 5: to build a dam at $105 \mathrm{~m}$, with the only caveat of reducing the water allocation by $13 \%$. However, many actors were negatively surprised that although the UNOPS team developed a scenario with climate change and future water demand (scenario 4; see Fig. 2), these changing future conditions were not included in their scenario 5, which only considers current water demand and ignores reduced water availability due to climate change. Therefore, we considered it important to replicate the results developed by the UNOPS team and to test and analyze its choice of scenarios and recommendation by developing an additional scenario ("our" scenario in Fig. 2) that added to scenario 5 the vari- 


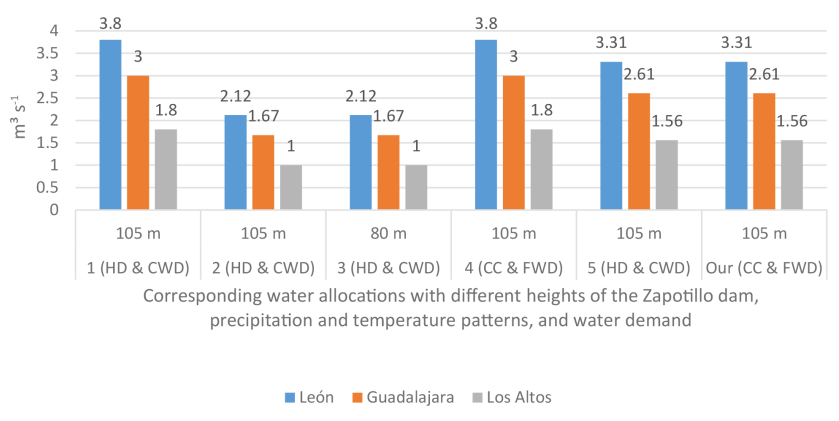

Figure 2. Key variables of the five water allocation scenarios (in $\mathrm{m}^{3} \mathrm{~s}^{-1}$ for León, Guadalajara, and Los Altos) developed by UNOPS (2017b) and our scenario. "HD \& CWD" is the historical runoff data and current water demand; "CC \& FWD" is the runoff under climate change and future water demand.

ables climate change and future water demand as developed by the UNOPS team in scenario 4 (Fig. 2). We then compared the results of our scenario with the original scenario 5 using the same indicators the UNOPS team used to assess their own scenarios. These indicators (reliability, vulnerability, and resilience) were based on the methodology of Loucks and Gladwell (1999). The reliability indicator assessed the percentage of months the dam was able to supply its intended volume. The ideal score would be $100 \%$. The vulnerability indicator assessed the percentage of water supplied vis à vis water demand for all months. The ideal score would also be $100 \%$. And the resilience indicator assessed the speed of recovery of the dam after a period of being empty by calculating the number of times a satisfactory value (when all water demand is satisfied) follows an unsatisfactory value (when not all water demand is satisfied) divided by the number of unsatisfactory values. The scores range from 1 to 0 , with a score close to 1 representing a highly resilient system and 0 a poorly resilient system ${ }^{3}$.

\section{Results}

\subsection{The Zapotillo conflict}

Guadalajara and León are the most important cities of their respective states, Jalisco and Guanajuato, in terms of population and economic size. Since the 1950s, Guadalajara's local water resources availability has been overrun by the increasing water demand, and water managers have sought to increase its water supply from Lake Chapala, the largest lake in the country. Currently, Guadalajara complements its water demand mainly through groundwater (see Table S1 in the Supplement). However, due to their intense use, the aquifers are considered as being overexploited, and nitrate

\footnotetext{
${ }^{3}$ The resilience indicator is only useful when the system presents unsatisfactory values; therefore if the system does not present any unsatisfactory values, the indicator is nonexistent, as seen in Fig. 6.
}

and sulfate are present due to farming activities and wastewater disposal, as well as naturally occurring contaminants like lithium, manganese, fluorine, and barium due to the mixing of hydrothermal fluids (Hernández-Antonio et al., 2015; Mahlknecht et al., 2017; Morán-Ramírez et al., 2016). León, on the other hand, does not have large bodies of surface water in its close vicinity, and therefore it has historically relied solely on groundwater, which is now considered as being heavily overexploited with a drawdown of $1.5 \mathrm{~m} \mathrm{yr}^{-1}$ and with the presence of chromium due to industrial activities, related to nitrate, chloride, sulfate, vanadium, and pathogens from anthropogenic activities and naturally occurring contaminants like fluoride, arsenic, iron, and manganese due to the introduction of older groundwater with longer residence times (Esteller et al., 2012; Villalobos-Aragón et al., 2012; Cortés et al,. 2015; Sapal, 2020).

During the 1980s, water managers in Jalisco were aware of the relentless growth of Guadalajara and sought to develop new sources of water besides groundwater and Lake Chapala (Flores-Berrones, 1987). They established that the only nearby region with enough water to supply Guadalajara was the Verde River basin, located in the north of Jalisco (Fig. 1). They calculated a potential of more than $20 \mathrm{~m}^{3} \mathrm{~s}^{-1}$, enough to supply water for Guadalajara for the coming decades. However, it was technically complicated to develop the Verde River basin and transfer its water to Guadalajara. The Verde River discharges into the Santiago River at around $500 \mathrm{~m}$ below the altitude of Guadalajara, which skyrockets pumping energy costs. During the 1990s Jalisco developed many projects that failed to materialize due to financial and political issues (Von Bertrab, 2003). During this time, and partially because of the inability of Jalisco to materialize a water transfer project, Guanajuato requested Conagua (the federal water authority) to provide legal rights over a portion of the Verde River's water for the city of León. In 1995, Conagua accepted this request and added Guanajuato as a potential user of the river's water.

During the year 2000, a drought started in the LermaChapala basin that caused a water crisis for Lake Chapala, which decreased its volume to less than $10 \%$ of its capacity. Since Guadalajara heavily relied on the lake for its water supply, and upstream farmers in Guanajuato used most of the surface water that fed the lake, the situation triggered a surface water allocation conflict between Jalisco and Guanajuato (Godinez-Madrigal et al., 2019). The conflict was resolved by reducing the water rights of upstream farmers to increase the volume of water reaching the lake. But, in exchange, in 2003 Conagua promised to build the San Nicolás dam in the Verde River basin to transfer water to León and the Arcediano dam in the Santiago River for Guadalajara (Godinez-Madrigal et al., 2019).

After a swift mobilization of the San Nicolás community, the dam was canceled in 2004. However, in 2005, the Zapotillo project was unveiled. It was designed with a height of $80 \mathrm{~m}$, with the objective to provide $3.8 \mathrm{~m}^{3} \mathrm{~s}^{-1}$ only to León. 


\section{THE HISTORY \\ OF}

the Zapotillo conflict

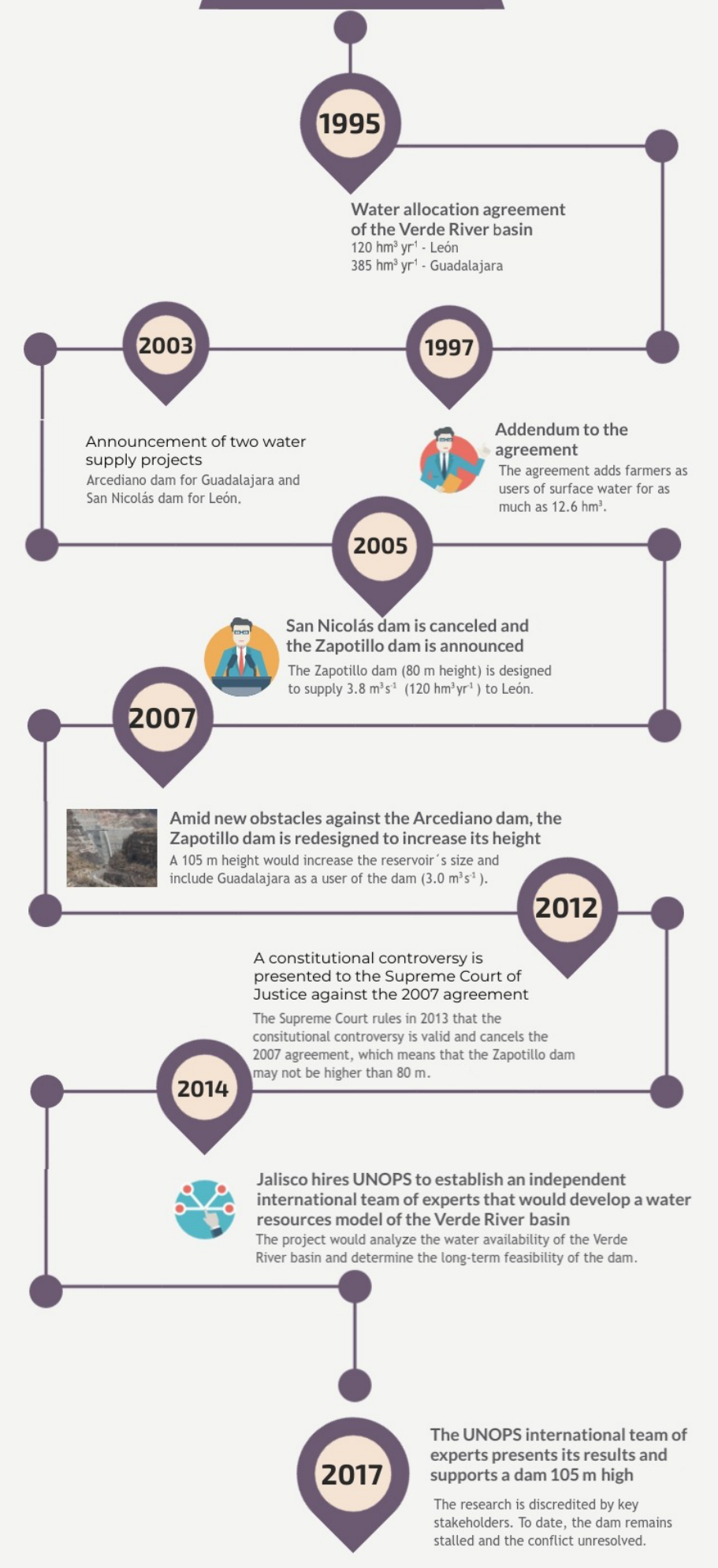

Figure 3. Timeline of the Zapotillo conflict. 
It is at this moment in time that the authors pinpoint the start of the Zapotillo conflict, which is summarized in Fig. 3. Nevertheless, because the water authorities could not solve important social, financial, and technical issues to build the Arcediano dam (López-Ramírez and Ochoa-García, 2012), Jalisco's government advocated in 2007 to change the design of the Zapotillo project to include Guadalajara as a user and receive $3.0 \mathrm{~m}^{3} \mathrm{~s}^{-1}$ by increasing the dam's height to $105 \mathrm{~m}$ to increase its storage capacity. ${ }^{4}$

By this time, the dam-affected communities, Temacapulín, Acasico, and Palmarejo (hereafter Temacapulín), had already started showing fierce opposition to the project, with the objective of avoiding the flooding and relocation of their communities. Their representatives followed a social and legal strategy which consisted of claiming that the 2007 agreement was unconstitutional because Jalisco's governor did not consult the state congress. In 2013, the Mexican Supreme Court ruled against the 2007 agreement and ordered Conagua to stop the construction of the dam, which by then already had reached $80 \mathrm{~m}$ height (DOF, 2013). The Zapotillo project has remained paralyzed since then. Although the dam wall has already been built, the reservoir has not been filled because of the uncertainty of the dam's final height.

Given the politicization of the conflict and the urgency of meeting the water deficits of Guadalajara and León without implementing any additional or alternative strategy, new actors have entered the political arena (see Fig. 4 for a comprehensive map of actors of the Zapotillo conflict). Some farmers' associations of Los Altos coalesced and lobbied against the Zapotillo project, using the argument that the region is semi-arid and already presents groundwater overexploitation, that climate change will worsen the condition of the regional water resources, and that the region is one of the most productive agricultural regions in the country (OchoaGarcía et al., 2014). Additionally, due to the increased political pressure, in 2014 Jalisco's government supported the creation of the Citizens' Water Observatory, led by an active spokesperson of farmers of Los Altos and composed of a wide range of representatives of universities and civil society organizations (see Supplement for more information) that would, at least in theory, have the mandate to formulate binding recommendations to local and state governments of Jalisco. The Observatory, NGOs, and local universities argued that demand management strategies in Guadalajara and León could be more sustainable and socially just than the Zapotillo project. In contrast, IMTA (the engineering body of Conagua) released a technical study concluding that the Zapotillo project was feasible (there was enough water availability in the basin), even in the context of climate change (IMTA, 2015).

\footnotetext{
${ }^{4}$ Several urban locations in the Los Altos region were included as well in the water allocation agreement of the project, which would receive $1.8 \mathrm{~m}^{3} \mathrm{~s}^{-1}$.
}

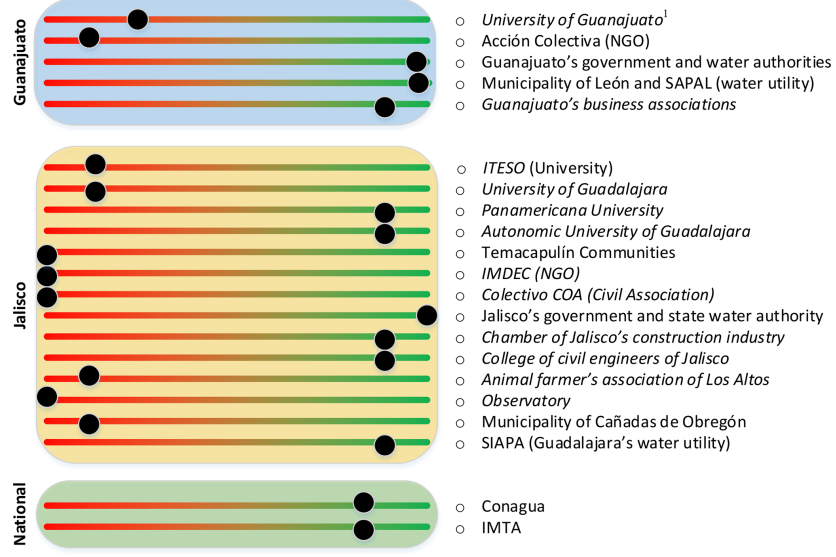

Figure 4. Position of key actors on a horizontal axis against (left, red) and in favor of (right, green) the Zapotillo dam project. New actors are highlighted in italics (for more details on the figure methodology and description of actors, see Table S2).

${ }^{1}$ Universidad de Guanajuato has not released any official position on the project; however many of its academics have publicly supported its cancelation.

In 2014 Jalisco's government hired the United Nations Office for Project Services (UNOPS) to establish an independent international team of experts tasked to develop a water resources model of the Verde River basin and formulate an informed recommendation to address, once and for all, the controversies regarding the possible negative effects in the Verde River basin and analyze the optimal configuration of the Zapotillo project. The involvement of UNOPS was immediately seen as an existential threat to the recently created Observatory because the latter assumed its primary function to be to determine the future of the Zapotillo project and recommend actions to solve the conflict. In fact, the chair of the Observatory criticized the involvement of UNOPS as a political play by Jalisco's government to decrease the Observatory's influence. He also questioned the integrity of the UNOPS team due to the apparently suspicious high cost of the study (USD 4.5 million) and refuted ex ante the technical study of the UNOPS team. Based on these criticisms, the leadership of the Observatory lamented that Jalisco's government had not funded them and the University of Guadalajara instead to do the research. However, an anonymous highlevel official of Jalisco's government (personal communication, 22 May 2017) characterized the criticisms from the Observatory as representing the political interests of the University of Guadalajara, who often lobby Jalisco's government to receive more financial resources (Jalisco's government determines the University's budget) and research contracts. Moreover, Jalisco's government had previously awarded environmental research projects to academics of the Universidad de Guadalajara, but, according to the official, the resulting studies were technically deficient and unusable. Related to IMTA, the appreciation of this official was that its func- 
tion has been relegated to technically legitimize Conagua's projects and that it was reluctant to share any information. The official concluded that "the scientific debate is very poor because it has been co-opted by politics". This explains why Jalisco's government neither trusted the University of Guadalajara nor IMTA and that it approached UNOPS as an alleged apolitical third party with proven independence (UNaffiliated) and technical capabilities that were locally absent to help solve the conflict. The government official said that "[Hiring] UNOPS will articulate a paradigmatic change in the way we make decisions on water management in Jalisco".

The UNOPS team's study took 2 years, and the process followed and methods adopted were largely unknown by most actors. Finally, in 2017, the UNOPS team of experts recommended that the Zapotillo dam should be built at $105 \mathrm{~m}$ height and that the original water allocation should decrease by $13 \%$, since Conagua had overestimated the available water in the Verde River basin and underestimated water demand (UNOPS, 2017c). The results of the study were discredited and discarded by some of the main stakeholders in the conflict as described in Sect. 4.3.

\subsection{Controversies}

Table 1 summarizes the main controversies and frames raised by the interviewed actors in the conflict. These can be divided into two: (1) what the appropriate policies to solve the water scarcity problems in the recipient basins (Guadalajara and León) are and (2) what the risks, uncertainties, and negative effects of a dam and water transfer in the Verde River basin, the donor basin, are.

\subsubsection{Recipient basins: policies for urban water security}

Since the 1980s, Guadalajara's water use per capita has remained above $200 \mathrm{~L}$ per capita per day (Flores-Berrones, 1987; Consejo Consultivo del Agua, 2010). Ever since, water authorities have strived to keep pace with the fast-growing city population because they consider a relatively large water use per capita to be an important indicator of water security. In the context of decreasing water availability per capita because of population growth, the actors in favor of the $\mathrm{Za}$ potillo dam project have emphasized the urgent necessity of supply augmentation for the cities of León and Guadalajara. Representatives from CEA Jalisco (Jalisco's water authority) and Sapal (León's water utility) argued that without supply augmentation, both cities might suffer a water crisis due to water scarcity derived from the overexploitation of its aquifers. Water authorities from Jalisco and Guanajuato concluded that pressure on aquifers in both cities and Lake Chapala needs to be decreased, as aquifers represent a safe backup in times of drought. An additional risk for Guadalajara is the aging Lake Chapala aqueduct, whose life expectancy has already been exceeded. Repairing the aque- duct may affect the water supply for the city for weeks or even months.

Opposing this argument, representatives of Temacapulín, the Observatory, NGOs, and universities have argued that supply augmentation will always lag behind water demand. This group of opposing actors argues that there is an urgent need to curb the water use per capita and to limit the cities' physical expansion and demographic growth, supported by a transition to a demand management paradigm that considers a reduction of physical losses, the development of alternative water sources like rainwater harvesting, sectoral water transfers, and full cost recovery of water utilities.

Regarding urban rainwater harvesting, a group within the Universidad de Guadalajara (not a member of the Observatory) has been developing and promoting this solution over the last decade (Gleason-Espíndola et al., 2018). They claim that harvesting rain through household systems distributed across the city could eventually make a supply augmentation project such as the Zapotillo project unnecessary. However, according to their own estimates, the proposed system could harvest approximately $21 \mathrm{hm}^{3} \mathrm{yr}^{-1}$, which could account for only about $7 \%$ of the total water use of Guadalajara, which is $313 \mathrm{hm}^{3} \mathrm{yr}^{-1}$ (Siapa, 2017). Researchers at the University of Guanajuato calculated an approximate annual rainwater harvest of $27.3 \mathrm{hm}^{3} \mathrm{yr}^{-1}$ for the city of León, amounting to $33 \%$ of the total water use of $81 \mathrm{hm}^{3} \mathrm{yr}^{-1}$ (Tagle-Zamora et al., 2018). It should be noted, however, that both studies differed in their methodology and approach, and both did not account for implementation uncertainties, a reason for Jalisco's water authority to dismiss rainwater harvesting as a realistic option.

The Observatory has argued that the municipality of León and the government of Guanajuato should integrate their water resources at the basin scale to save water and reallocate it to where it is most needed. For this, Jalisco's Observatory proposed a two-way strategy for León: to abstract water from Sierra de Lobos, a mountain range located close to León, and to implement an agricultural water modernization program and to reallocate its savings to León. The Observatory claims such a strategy would increase available water for León to $360 \mathrm{hm}^{3} \mathrm{yr}^{-1}$, which is 4 times León's current water use (Del Castillo, 2018). However, even after requesting them, the technical details of this alternative have not been shared nor made public anywhere. In fact, an anonymous member of the Observatory recognized that the technical members of the Observatory produced these claims based on "feeling" rather than on technical analysis (personal communication, 8 May 2017).

When looking at a reduction of physical losses, Fitch Ratings (2015) stated that the current losses of Guadalajara's distribution system account for more than $3 \mathrm{~m}^{3} \mathrm{~s}^{-1}$ (around $32 \%$ of distributed flow). Gómez-Jauregui-Abdo (2015) warned that this situation may worsen because of the network's obsolescence rate, which is higher than the replacement rate. CEA Jalisco has argued that Siapa's budget is not sufficient to replace the entire distribution system and 
that even if sufficient financial resources were available, it would imply a huge social cost by breaking the asphalt of the streets of the whole city and paralyzing traffic. This would also imply a political cost that no local politician is willing to assume. In León, Sapal's nonrevenue water also amounts to approximately $32 \%$. Although the replacement rate of their distribution system is higher than Guadalajara's, their distribution system's deterioration rate is not precisely known.

Representatives of CEA Jalisco consider all these alternative solutions not only cumbersome and ineffective, but also too expensive to implement. However, IMDEC, the most outspoken NGO against the project, released public information of mounting costs of the Zapotillo project: the Zapotillo project's original budget (2006) was USD 750 million (USD 1250 million in today's value), which according to official estimates has increased to USD 1800 million (IMDEC, 2019). Considering these escalating costs, the NGO argues that demand management solutions (i.e., reduction of physical losses) could be more economical than this large infrastructure and avoid its large social costs.

A key anonymous actor opposing the project (personal communication, 15 May 2017) pointed out that officials of Jalisco's water authority are not interested in demand management strategies because they benefit the interests of large real estate companies who need more water rights to keep building housing developments: "it is the nature of capitalism, to keep growing [...] this [the Zapotillo conflict] is actually a class conflict".

\subsubsection{Negative consequences for the donor basin}

In the past decades Los Altos has experienced two major socioeconomic changes: first, a decreasing rural population due to migration to the United States (Durand and Arias, 2014) and to nearby cities in Jalisco, and second, the increasing industrialization of the regional economy. In the 1990s, Mexico liberalized its markets and supported agriculture for export. These policies helped industrialize the agricultural sector of Los Altos (Cervantes-Escoto et al., 2001). Currently, the region is the second largest producer of animal protein in the country (Ochoa-García et al., 2014) and hosts one of the largest egg producers in the world (WATTAgNet, 2015). This economic development has increased competition for water, especially groundwater, due to the government's restrictions on surface water use (DOF, 2018). Several water users confirmed the existence of a black groundwater market and groundwater rights' grabbing in the hands of industrial farmers. Consequently, most aquifers present serious water balance deficits, which jointly amount to more than $150 \mathrm{hm}^{3} \mathrm{yr}^{-1}$ in Los Altos' aquifers (CEA Jalisco, 2018), and many have the presence of selenium, fluoride, and arsenic (Hurtado-Jiménez and Gardea-Torresdey, 2005, 2006). As agricultural outputs keep increasing around $9 \% \mathrm{yr}^{-1}$ (Ochoa-García et al., 2014), groundwater overexploitation may be exacerbated in the future due to an increasing wa- ter demand. Although there are no clear numbers on the water balance for surface and groundwater separately, water authorities calculated a combined renewable water availability in the Verde River basin, which also includes groundwater in Aguascalientes (Fig. 1), of $1624 \mathrm{hm}^{3} \mathrm{yr}^{-1}$, while current water demand was $1804 \mathrm{hm}^{3} \mathrm{yr}^{-1}$ (Conagua-Semarnat, 2012).

The Observatory's leadership has defended the interests of Los Altos farmers by pitching the human right to food as being equally important as the human right to water, which is argued by Jalisco's government. Due to the water deficit in the basin and the effects of climate change, the technical chair of the Observatory has argued that there is insufficient water in the basin to fill the dam at the planned $105 \mathrm{~m}$ height and that, based on the precautionary principle, the Verde River basin should not be burdened with additional commitments due to a water transfer. Additionally, he stated that water information provided by gauging stations in the Verde River basin cannot be trusted, as the network of hydrological stations is allegedly defective and unattended.

An anonymous interviewee from CEA Jalisco (personal communication, 20 April 2017) did not deny the possibility of some defective hydrological gauging stations but claimed that even if it is true that runoff is overestimated in the basin, CEA Jalisco is confident that the gauging station at the entry point of the dam is reliable. This station has measured an average flow of $599 \mathrm{hm}^{3} \mathrm{yr}^{-1}$ (IMTA, 2015), which is enough to fill the Zapotillo dam in 1 year at a height of $80 \mathrm{~m}$ or in 2 years at a height of $105 \mathrm{~m}$. Currently the water from the Verde River flows to the Santiago River with only minor abstractions (UNOPS, 2017d). However, farmer representatives in Los Altos stated in a meeting that, even if these surface water resources of the Verde River exist (they insist that the flow of the river has dramatically decreased over the past years), these should be used to contribute to the potential growth of Los Altos.

The anonymous government official of Jalisco addressed this continuous growth of agricultural groundwater demand as the main sustainability problem in the basin and suggested farmers should become more efficient and stop groundwater overexploitation (personal communication, 22 May 2017), but such an endeavor might be more complex, as described by an anonymous representative of a large industrial protein producer in Los Altos (personal communication, 2 May 2017): "[Groundwater overexploitation] does not constrain economic development. [... ] If you need water you can get it in the black market. Because of corruption, Conagua cannot stop groundwater overexploitation". The procedure to acquire or renew a groundwater right is a legal conundrum that forces farmers to hire "coyotes" (literally: a relative of wolves; here officials within Conagua are meant that illegally ease the procedure for a considerable fee). This situation has forced smallholder farmers to sell their lands for a penny and migrate when they cannot renew their groundwater rights, since, as three interviewees confirmed, "a land without water is worthless". Large pro- 
ducers have the means to hire coyotes and have been grabbing water rights and large portions of land from impoverished farmers.

Regarding the dam's height and the three communities under threat of displacement, the controversy lies in incompatible values. These communities reasserted their rights of consultation and consent, participation, and the protection of their cultural and historical heritage. In turn, the government of Jalisco reasserted the utilitarian argument of the greatest good for the largest number of people. Temacapulín's representatives proposed a dam with a height of $60 \mathrm{~m}$, whereby the towns would be safe from flooding. However, a smaller dam would not be able to transfer the agreed volume of water to Guadalajara and León, since the dam's storage capacity would then be $145 \mathrm{hm}^{3}$, too small to sustain a steady water transfer of $8.6 \mathrm{~m}^{3} \mathrm{~s}^{-1}$. At a height of $80 \mathrm{~m}$, Temacapulín, Acasico, and Palmarejo would be flooded. However, CEA Jalisco's representatives claimed that the construction of dikes could prevent this, albeit only for Temacapulín. IMDEC, the NGO accompanying the affected communities, and representatives of Temacapulín are against this solution as it would create a huge unnecessary risk for the inhabitants in case the dikes fail. Moreover, an $80 \mathrm{~m}$ dam with a capacity of $411 \mathrm{hm}^{3}$ would not be able to allocate sufficient water for both León and Guadalajara. With a height of $105 \mathrm{~m}$ and a storage capacity of $910 \mathrm{hm}^{3}$, the dam could potentially supply sufficient water for Guadalajara, León, and Los Altos.

\subsection{Analysis of scientific products}

The history of the conflict over the Zapotillo project has created several scientific products that have attempted to address the many uncertainties and risks of a project of this magnitude. But most of them have not analyzed the system in an integrated way. The first one (IMTA, 2005) assessed the relationship between the dam's size and its maximum water yield. Although this study explored scenarios of future water demand in the donor basin, it did not explore scenarios of the effect of climate change on precipitation, which is officially recognized as being likely to decrease in Jalisco (Martínez et al., 2007). Moreover, the study did not consider the effect of increasing groundwater overexploitation in the basin on the base flow of the river. The study recommended the most optimistic scenario where surface water use in the donor basin would not increase in the future.

Conagua $(2006,2008)$ subsequently released the Environmental Impact Assessment of the project, which dismissed any potential negative impact on the donor basin, based on the argument that local farmers have already caused most of the environmental degradation. However, the study analyzed the impact of the dam only at the dam site, not the overall regional impact (CACEGIAEJ, 2018). Later, when the dam design was redesigned to $105 \mathrm{~m}$ in 2007, IMTA did not release any complementary study to assess the implications of a larger reservoir area, of an additional water user (Guadalajara), or of a higher water allocation.

In 2014, the Los Altos Animal Farmers' Association commissioned ITESO (the Jesuit University in Guadalajara) to study the possible social effects of the water transfer. The study (Ochoa-García et al., 2014) concluded that according to official data, the Los Altos region already had a groundwater deficit of more than $100 \mathrm{hm}^{3} \mathrm{yr}^{-1}$ and growing, due to the continuing growth of the agricultural output of the region. It also concluded that, since the region's climate is semi-arid, the region was especially vulnerable to droughts; hence the water transfer project would have serious negative socioeconomic and environmental effects. However, the study could not make a surface water assessment nor a climate change analysis due to lack of information. Recently, the Observatory made a haphazard water footprint analysis public to assess the water needed for supporting the agricultural activity in the region (Ágora, 2018). It concluded that the water footprint of Los Altos agricultural output was $14081 \mathrm{hm}^{3} \mathrm{yr}^{-1}$; therefore the $12 \mathrm{hm}^{3} \mathrm{yr}^{-1}$ allocated to animal farming in the allocation agreement of the Verde River of 1997 was insufficient. However, this argumentation is flawed, since they did not consider that the water footprint of a given agricultural product includes the virtual water imported from other regions in the form of fodder. So, the actual water needed by the region is much less than $14081 \mathrm{hm}^{3} \mathrm{yr}^{-1}$.

To counter the study of Ochoa-García et al. (2014) and to prove that there was enough water availability in the basin, CEA Jalisco conducted a new water availability study (IMTA, 2015). Although this time the study included climate change as a variable in the water resources by using IPCC's regional models based on RCP4.5 and RCP8.5 climate scenarios, the study discarded the negative effects of climate change on the water balance due to its high uncertainty: "Climate change results should not be analyzed deterministically, but probabilistically... [we should not lose] perspective that climate change studies are still in an early stage; thus, their results cannot be taken as absolute truths, due to their low probability of occurrence. ... There is no certainty that projected rainfall and temperatures in climate change models will occur" (our translation from IMTA, 2015, p. 212). The study did not consider possible future increases in water demand, nor did it evaluate the dam's behavior according to input variables (river runoff) and output variables (water allocation and other losses). As a result, the study could conclude that sufficient water was available in the Verde River basin to comply with the water allocation agreement and environmental flows for the coming decades. The study was discredited by the leadership of the Observatory, who accused IMTA of allegedly forging data.

What can be concluded from the previous studies is that there were at least four important uncertainties that were still ignored: (1) physical groundwater processes and the interaction between groundwater and surface water in the Verde River basin, (2) the effect of future water demand in Los Al- 
tos' water resources, (3) the effect of climate change, and (4) the potential impact on water quality and ecosystem services downstream in the Santiago River. Moreover, the studies did not consider other possible alternatives to the $\mathrm{Za}$ potillo project for water supply to Guadalajara and León.

As previously mentioned, in late 2014, Jalisco's government hired UNOPS to develop a comprehensive water resources model of the Verde River basin. The UNOPS multidisciplinary team of international experts addressed the four uncertainties in the following way. (1) They analyzed groundwater dynamics by using information from NASA's GRACE earth observation project. (2) For 2 years, the team collected social and hydrological information in situ from the Verde River basin to estimate current water demand and project future water demand. (3) They used IPCC's RCP8.5 regional model of climate change for Los Altos. (4) They calculated environmental flows downstream of the Zapotillo dam. These analyses were used as input variables for the water resources model of the Verde River basin using WEAP software, which allowed for the simulation of future scenarios (for a more detailed description of the model, see the Supplement).

After months of speculation over the UNOPS team's results, the team released a preliminary study, which found that current water demand was $50 \%$ higher compared to official data (UNOPS, 2017c). Months later, they presented the final results in a public meeting (29 June 2017). The UNOPS team developed five main scenarios with different variables (see Fig. 2). Although the UNOPS team could have developed many other scenarios with different variables, the report of the study justified choosing these five scenarios in the following way:

The definition of the number of scenarios is not absolute but may be subject to future changes at any time that it is required to attend to different questions from those raised in the framework of this study. [... ] Specifically, it is interesting to know under which configuration of the dam's height and volume of water transfer can guarantee [the satisfaction of] water demand and what percentage of satisfaction corresponds to it, which leads to justifying technically the presence of the dam and its geometric configuration. It is important to be clear that this focus considers only the hydrological aspects related to the satisfaction of demands. Any other conclusion about the configuration of the Zapotillo project needs to be complemented by broader technical analyses [...] social and economic evaluations, among others, which fall outside the scope of this study. (UNOPS, 2017b, p. 27-28)

They assessed the performance of each scenario based on reliability (to supply urban water), vulnerability (volume of unmet water demand), and resilience (of the dam to recover its water levels after an empty period) indicators. The UNOPS team concluded that only scenario 5 scored positively on the three indicators. However, the good performance of scenario 5 (Fig. 2) depended on reducing the volume of water to be transferred to León, Guadalajara, and Los Altos by $13 \%$ in accordance with the 2007 agreement. The UNOPS team recommended Jalisco's government to proceed with the project with such settings and a dam height of $105 \mathrm{~m}$. Jalisco's governor immediately confirmed this decision during the public presentation of the results: "We are going after the benefit of the majority and what Jalisco needs. [... ] May history single me out for being the harbinger of the services that our people need".

The consultants immediately left the venue after the presentation, leaving no time to discuss with the attending stakeholders the key assumptions of the model or the justification and relevance of the five scenarios. Temacapulín's representatives reacted negatively, as their community would be flooded, and took over the podium and declared: "[The government] paid 4.6 million dollars for this stupid study. It's not a real study; it is a study of lies" (our translation). Later, Temacapulín's representatives demonstrated in front of Jalisco's government main building and declared that "we do not accept the UNOPS team's recommendation because the decision was made beforehand [...] [the UNOPS team] did not research for alternatives; all the variables referred to the dam" (our translation).

The local academics criticized the UNOPS team's study for not considering climate change nor future water demand in scenario 5, the limitations of the chosen indicators, and the still incomplete assessment of groundwater given the low reliability of GRACE's coarse spatial resolution data. Members of the Observatory interpreted these omissions in the study as being deliberate: "[T]hey applied a methodology that was biased to get the results that we heard [in the presentation]: a $105 \mathrm{~m}$ dam [...] It makes me worried that organizations like this [UNOPS] are being used to do this kind of research. [...] We will surely present a formal complaint in the United Nations" (this is an excerpt from a public interview with the head of the Observatory; Radio UdeG Guadalajara, 2017, our translation).

To explore the possibility of a deliberate omission, Fig. 5 shows a comparison between scenario 5 and our own scenario, which configures a scenario with the allocation variables of scenario 5 and the climate change and future water demand variables of scenario 4, as described in Sect. 3 and illustrated in Fig. 2. The results show a poor performance of the Zapotillo dam's projected storage and the three indicators chosen by UNOPS (Fig. 6). Whereas scenario 5 shows all three indicators (reliability, vulnerability, and resilience) on target, our scenario results in substantially lower performance, notably in vulnerability and resilience. Therefore, the poor results of these indicators do not seem to justify the implementation of the Zapotillo project as it is currently designed. 


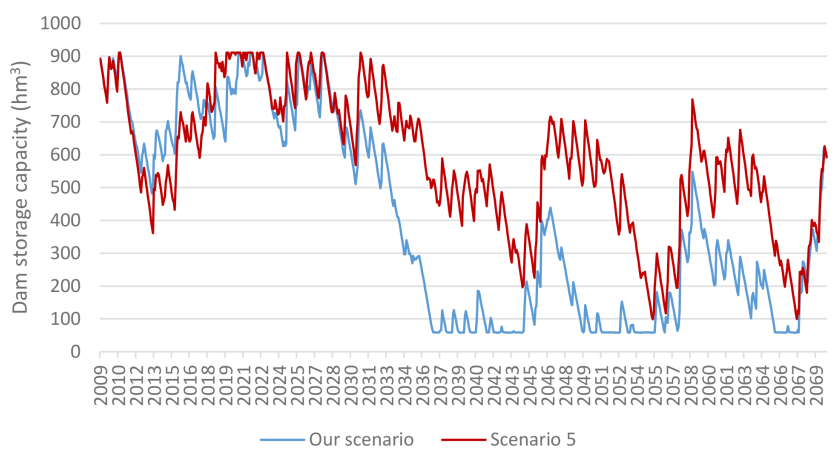

Figure 5. Comparison of Zapotillo dam's behavior in scenario 5 (UNOPS, 2017b) and our scenario, which includes climate change and future water demand.

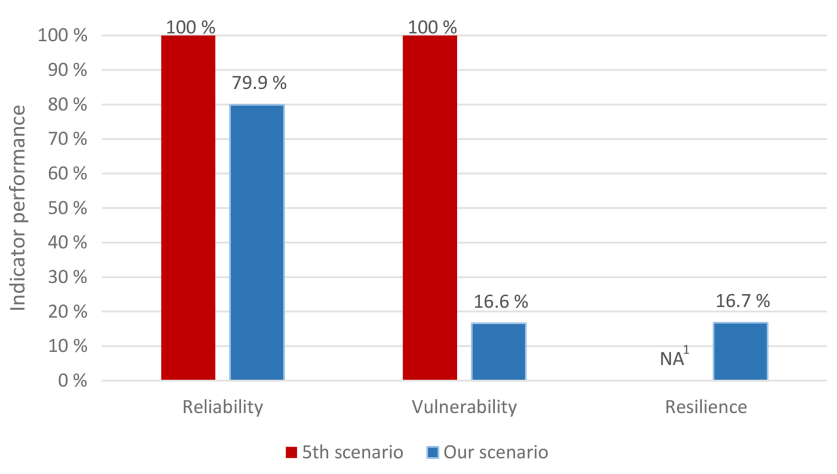

Figure 6. Performance of the indicators for the two scenarios.

1 NA denotes "not applicable"; the resilience indicator only applies when the scenario projects the water storage in the dam to reach the minimum level, impeding water supply to its users.

\section{Discussion}

Since large infrastructural projects are still depicted as the main solution to current water problems (Muller et al., 2015; Boelens et al., 2019), it is important to critically assess the uncertainties embedded in the scientific products that support such projects in the face of the social and environmental costs they can cause. In the case of the Zapotillo project, we found that although substantial effort had been made to reduce uncertainties, those efforts were directed towards reducing uncertainties of accuracy and precision, which partially addressed epistemic uncertainties but not the ambiguity of multiple frames: is supply augmentation the only solution for Guadalajara and León, or are there alternative solutions? Should the benefit of the majority trump the rights of a minority? The UNOPS team of experts improved the assessment of four uncertainties: climate change, future water demand, groundwater dynamics, and environmental flows in the Verde River basin. It however did not improve the understanding of the Zapotillo project's adequacy to improve the urban water problems of Guadalajara and León nor of how and to what extent the Zapotillo project would negatively affect stakeholders in the donor region.

Regarding the efforts to reduce the four uncertainties of accuracy and precision identified in the previous section, the UNOPS study improved the knowledge of the system but not without caveats. Since the effects of climate change depend on the severity (moderate or extreme) of the chosen IPCC climate scenarios, IMTA and the water authorities seemed doubtful to accept this uncertainty in their decision-making and removed climate change as a factor to consider when developing large hydraulic infrastructure. The water balance assessment by UNOPS (2017c) found that Conagua was underestimating water demand and revealed a serious overexploitation of surface and groundwater in the Verde River basin. Given the difficulty of properly estimating current water demand, future water demand became a large uncertainty. The third uncertainty is still largely unresolved: the groundwater situation in the Verde River basin. Conagua lacks sufficient measuring infrastructure to gauge the state of the aquifers, and there are no long-term series of groundwater levels available. Also, the use of earth observation (GRACE) by UNOPS to estimate groundwater added little new information; it may even have been inappropriate, given the very coarse spatial resolution of GRACE, rendering it only suitable for very large aquifers, much larger than the Verde River basin aquifers (Castellazzi et al., 2018; Vishwakarma et al., 2018). Finally, as in all previous studies, the study by UNOPS also ignored possible downstream effects of the dam beyond the city of Guadalajara and as far as the natural outlet of the receiving Santiago Basin in the Pacific.

Since the UNOPS team did not address the epistemic controversies and ambiguity related to the (un)feasibility of the project, the possible alternatives for water supply in the recipient regions, the possible negative effects in the donor basin, and the injustice and unfair treatment of communities in the vicinity of the dam, the results of the study by UNOPS remained contentious and mistrusted. Considering the goal of urban water security, the model by UNOPS seemed to answer the wrong research question to address the ambiguity of the conflict: how can the management and operation of the Zapotillo project be optimized to guarantee the satisfaction of water demand in Guadalajara and León? Deciding on this research question was a political choice that determined the outcome of the research, since it implied that the decision to proceed with the infrastructure had already been taken and that the only valuable decision criteria are those related to optimizing the water supply to Guadalajara and León with that infrastructure, leaving other controversies described in this paper unaddressed. The reaction of actors to the study by UNOPS is clear: their impression was that the study and research was restricted only to the dam configuration, which was only one issue, among many, of the problem and the conflict.

The importance of asking the right question is highlighted by DFID (2013) and Feldman and Ingram (2009), who ar- 
gue that the impact of research and development may decrease when it lacks a deliberative process with stakeholders, including in the definition of what the research questions are. In general and since the 1990s, research has been consistent in promoting knowledge co-production to solve pressing and disputed environmental problems (i.e., Funtowicz and Ravetz, 1994; Van Cauwenbergh, 2008; Brugnach et al., 2011; Islam and Susskind, 2018; Armitage et al., 2015; Norström et al., 2020). The UNOPS team therefore missed the opportunity to answer a much more relevant question for all actors in the conflict that is based on decision criteria (and indicators) agreed by all stakeholders: how does the Zapotillo project compare to alternative solutions for creating a sustainable and socially just urban water system?

The knowledge generated by the UNOPS team effectively filtered out other feasible solutions to the water problems of the three regions in conflict and did not take into consideration downstream users nor environmental flows for the Santiago River. If the goal is to achieve water security and solve a water conflict, then it was not justified to restrict the research and modeling to supply augmentation scenarios with the $\mathrm{Za}$ potillo project. According to the best social and hydrological knowledge available, it can be inferred from our scenario that there are insufficient surface water resources to satisfy the demand of the three regions' explosive demographic and economic growth, which means that at least one region will continue to unsustainably deplete its groundwater resources. In fact, the fifth scenario in the study by UNOPS generated positive results only because it considered null demographic and economic growth for the future and did not consider climate change in the Verde River basin.

The case and the persistence of the conflict blocking the dam project shows that water authorities have lost their power to impose their decisions and need the support and legitimacy of the incumbent social actors in the donor region. Given the absence of a legitimate authority to enforce decisions, actors from the three regions have entered the knowledge arena to build their cases that support their interests. Norström et al. (2020) proposed that pluralistic, goal-oriented, interactive, and context-based knowledge coproduction can improve system understanding and reduce conflicts. The opposite also seems to be true - when actors in conflict produce knowledge only in relation to their interests and in isolation, they reinforce their frame and lose the overall perspective of emerging problems in the coupled water-human system at hand. In those cases, science is not able to depoliticize the conflict, but instead the conflict ends up politicizing the science-policy process. This became evident when most actors in the conflict produced or claimed unverifiable knowledge which was never put to the test. In contexts of conflict, creating agonistic spaces to test knowledge is an important process to positively challenge knowledge claims and stakeholders' frames (Krueger et al., 2016). However, there was a lack of systematic analysis, methodological transparency, and open discussion from which firm conclusions could be drawn from the side of both the water authorities and opposing actors like the Observatory, academics, communities, and the NGOs. Especially the Observatory produced unverifiable but allegedly scientific knowledge that hardened the multiple frames at play and contributed to an increased ambiguity and partisan science.

Although the conflict is related to the control of surface water resources, groundwater seems to be a defining issue and emerging problem in the conflict. The three regions are competing for limited surface water resources, aimed at protecting their available groundwater resources and their current and future demographic and economic growth. However, given the heavy reliance on groundwater for water supply, other threats seem to have been overlooked. Water quality and land subsidence have been almost absent in the debate, even though there is increasing evidence that groundwater quality is rapidly declining and land subsidence is increasing as overexploitation intensifies (for Guadalajara, see Hernández-Antonio et al., 2015; Morán-Ramírez et al., 2016; Mahlknecht et al., 2017; for León, see Villalobos-Aragón et al., 2012; Cortés et al., 2015; Hoogesteger and Wester, 2017; and for Los Altos, see Hurtado-Jiménez and GardeaTorresdey, 2005, 2006, 2007).

This case study serves as a cautionary tale for actors in a water conflict, who are embroiled not in solving the problem, but in implementing their own preferred solution. Madani (2010) warned that the behavior of noncooperative actors might result in a worse condition for all. Although science has the potential to bridge the positions of actors, it can also be misused by hegemonic actors to support their own solutions. However, as this case exemplifies, that can be counterproductive and backfire instead.

\section{Conclusions}

This paper sought to scrutinize and unravel the entanglement of politics and science in the production of water knowledge for intractable conflicts, by analyzing the case of the Zapotillo conflict in Mexico. The conflict is defined by epistemic uncertainties, ambiguity, and incompatibility of values. The first two consist of several knowledge controversies regarding water availability and the negative effects of the water transfer and dam construction in the donor basin, as well as the possible alternatives to supply augmentation strategies in the recipient basins. The latter consists of a dispute over the distribution of the environmental, social, and economic costs and benefits derived from the Zapotillo project.

This study has two main findings. (1) Intractable water conflicts tend to isolate the process of knowledge production, which foregrounds issues that are politically convenient for each actor, while other issues, perhaps more important for sustainability (like groundwater overexploitation), are concealed and remain unaddressed. (2) Isolated knowledge has less potential for transforming the conflict by missing 
core epistemic uncertainties and pushing value-laden knowledge claims as facts. After analyzing the model of UNOPS, we found that its research team made a significant contribution to knowledge by reducing uncertainties related to the precision and accuracy of future water demand, climate change, groundwater dynamics, and ecological flow. But the team failed to address epistemic uncertainty around emerging problems induced by groundwater overexploitation as well as ambiguity related to the negative effects in the donor basin and more sustainable and socially just alternatives to the Zapotillo project. We found some indications that the UNOPS team indulged into what Boelens et al. (2019) call the manufacture of ignorance, by recommending Jalisco's government to build a $105 \mathrm{~m}$ dam without taking into account climate change, future water demand, or alternative water supply options. But this result may also be explained by the absence of efforts by the UNOPS team to facilitate the coproduction of knowledge. So, even if the UNOPS team did not deliberately indulge in the manufacture of ignorance by building a water resources model based on political interests, its research suffered from tunnel vision by inadequately managing the ambiguity of the conflict. Nevertheless, the mere suspicion of deliberate manufacture of ignorance was enough to discredit UNOPS results by most stakeholders. However, contrary to the conclusion of Boelens et al. (2019), deliberate production of biased knowledge is not exclusive to powerful actors. Instead, this kind of knowledge was produced by most of the actors in the conflict.

Returning to the original question as to whether science can depoliticize conflicts or whether science is politicized in the process, this case has shown that attempting to depoliticize science-policy processes is very difficult, since these processes are inherently political. Moreover, involving alleged neutral - or apolitical - third parties to depoliticize scientific knowledge to resolve water conflicts can backfire if they act - or are perceived - as stealth advocates of political interests. However, we identified two elements that can contribute to a possible transformation of the conflict and management of such politicization. First, scientists in contexts of conflict should be aware of not promoting specific solutions, since that is the role of the political actors. When scientists assume the role of "honest broker of policy alternatives" (Pielke, 2007), it restrains them from offering a specific course of action and compels them to expand the scope of choice for the actors in the conflict. Second, it is necessary to promote social mechanisms to filter as much as possible which knowledge claims are more value-laden and which are less so, particularly in contexts of conflict and high uncertainties. There is an urgent need to design water resources models in a more open way to allow for the participation of stakeholders and legitimize the data used in them (Islam and Susskind, 2018) as well as the values hidden in them; this can support the necessary task of reviewing alternatives to large infrastructures (Gupta and van der Zaag, 2008). Additionally, fostering stakeholder participation could collaboratively bring about socially relevant research questions that open the decision space (Voinov and Gaddis, 2008; Zimmerer, 2008; Budds, 2009; Lejano and Ingram, 2009; Brugnach et al., 2011; Blöschl et al., 2013; Armitage et al., 2015; BascoCarrera et al., 2017; Van Cauwenbergh et al., 2018; van der Molen, 2018; Norström et al., 2020). Brugnach et al. (2011) support this as one of the main strategies to handle ambiguity, albeit with the drawback of necessary high social skills to bring people together, which, in a context of conflict, is difficult to achieve. However, despite this difficulty, attempting such an effort could already improve the capacity to innovate by incorporating new perspectives, as suggested by Brugnach et al. (2008), and by identifying arbitrary decisions in public policies by hegemonic actors. Such transparency could decrease the capacity of powerful actors to capture the sciencepolicy process. However, further research is needed to evaluate if co-production of knowledge can bring about cooperation and consensus between the stakeholders and limit the influence of politics and vested interests in decision-making in water conflicts.

Code availability. The reader can access the Verde River basin model developed by the UNOPS team of experts and modified by the authors at https://github.com/jongmadrigal/Verde-River-Basin (Godinez Madrigal, 2019). Although the model is only accessible through the software WEAP (https://www.weap21.org, last access: 12 October 2020), it is possible to download the software for free and run its test version to replicate this article's findings. UNOPS data are available upon request.

Supplement. The supplement related to this article is available online at: https://doi.org/10.5194/hess-24-4903-2020-supplement.

Author contributions. JGM, NVC, and PvdZ conceptualized the paper. JGM conducted the data curation, formal analysis, and scenario development, while JGM and NVC conducted the interviews in situ. JGM wrote the original draft, while NVC and PvdZ reviewed and edited it.

Competing interests. The authors declare that they have no conflict of interest.

Special issue statement. This article is part of the special issue"Contributions of transdisciplinary approaches to hydrology and water resources management”. It is not associated with a conference.

Acknowledgements. We would like to thank the two reviewers and the editor for their useful comments on this paper. 
Financial support. This research has been supported by the Consejo Nacional de Ciencia y Tecnología (grant no. 409777).

Review statement. This paper was edited by Tobias Krueger and reviewed by Leticia Lima and Jeroen Vos.

\section{References}

Ágora: El problema del agua en los Altos de Jalisco, México, available at: https://www.facebook.com/agoraelperiodicodesanjuan/ videos/2172646786102206/ (last acess: 15 May 2019), 2018.

Armitage, D., de Loë, R. C., Morris, M., Edwards, T. W. D., Gerlak, A. K., Hall, R. I., Huitema, D., Ison, R., Livingstone, D., MacDonald, G., Mirumachi, N., Plummer, R., and Wolfe, B. B.: Science-policy processes for transboundary water governance, Ambio, 44, 353-366, https://doi.org/10.1007/s13280-015-0644$\mathrm{x}, 2015$.

Barraqué, B. and Zandaryaa, S.: Urban Water Conflicts: Brackground and Conceptual Framework, in: Urban Water Conflicts, Edn.: UNESCO-IHP Urban Water Series, edited by: Barraqué, B., CRC Press, 2011.

Basco-Carrera, L., van Beek, E., Jonoski, A., Benítez-Ávila, C., and PJ Guntoro, F.: Collaborative Modelling for Informed Decision Making and Inclusive Water Development, Water Resour. Manag., 2611-2625, https://doi.org/10.1007/s11269-017-1647$0,2017$.

Berkoff, J.: China: The South-North Water Transfer Project - Is it justified?, Water Policy, 5, 1-28, 2003.

Blomquist, W. and Schlager, E.: Political pitfalls of integrated watershed management, Society and Natural Resources, 18, 101117,2005

Blöschl, G., Viglione, A., and Montanari, A.: Emerging approaches to hydrological risk management in a changing world, in: Climate Vulnerability: Understanding and Addressing Threats to Essential Resources, edited by: Hossain F., Elsevier Inc. Academic Press, 3-10, https://doi.org/10.1016/B978-0-12-3847034.00505-0 2013.

Boelens, R., Shah, E., and Bruins, B.: Contested Knowledges: Large Dams and Mega-Hydraulic Development, Water, 11, 127, https://doi.org/10.3390/w11030417, 2019.

Brugnach, M. and Ingram, H.: Ambiguity: the challenge of knowing and deciding together, Environmental Science \& Policy, 15, 6071, 2012.

Brugnach, M. and Pahl-Wostl, C.: A broadened view on the role for models in natural resource management: implications for model development, in: Adaptive and Integrated Water Management, Springer, Berlin, Heidelberg, 187-203, 2008.

Brugnach, M., Dewulf, A., Pahl-Wostl, C., and Taillieu, T.: Toward a relational concept of uncertainty: about knowing too little, knowing too differently, and accepting not to know, Ecol. Soc., 13, 30, http://www.ecologyandsociety.org/vol13/iss2/ art30/, 2008.

Brugnach, M., Dewulf, A. R. P. J., Henriksen, H. J., and Van der Keur, P.: More is not always better: coping with ambiguity in natural resources management, J. Environ. Manage., 92, 78-84, 2011.
Brummans, B. H., Putnam, L. L., Gray, B., Hanke, R., Lewicki, R. J., and Wiethoff, C.: Making sense of intractable multiparty conflict: A study of framing in four environmental disputes, Commun. Monogr., 75, 25-51, 2008.

Budds, J.: Contested $\mathrm{H}_{2} \mathrm{O}$ : Science, policy and politics in water resources management in Chile, Geoforum, 40, 418-430, https://doi.org/10.1016/j.geoforum.2008.12.008, 2009.

Cabello, V., Kovacic, Z., and Van Cauwenbergh, N.: Unravelling narratives of water management: Reflections on epistemic uncertainty in the first cycle of implementation of the Water Framework Directive in southern Spain, Environmental Science and Policy, 85, 19-27, https://doi.org/10.1016/j.envsci.2018.03.019, 2018.

CACEGIAEJ - Comité Académico de la Comisión Especial para la Gestión Integral del Agua en el Estado de Jalisco: Los problemas de la gestión integral del agua y la Presa El Zapotillo, available at: http://almeida.org.mx/documentos/LibroDelAgua. pdf (last access: 12 October 2020), 2018.

Callon, M.: An essay on framing and overflowing: economics externalities revised by sociology, Sociol. Rev., 46, 244-269, https://doi.org/10.1111/j.1467-954X.1998.tb03477.x, 1998.

Castellazzi, P., Longuevergne, L., Martel, R., Rivera, A., Brouard, C., and Chaussard, E.: Quantitative mapping of groundwater depletion at the water management scale using a combined GRACE/InSAR approach, Remote Sens. Environ., 205, 408418, 2018.

CEA Jalisco: Disponibilidad Media Anual De Aguas Subterráneas En Acuíferos Del Estado De Jalisco De Acuerdo Con Lo Publicado En El Diario Oficial De La Federación (DOF) El Día 4 De enero De 2018, available at: https://www.ceajalisco.gob.mx/ contenido/acuiferos/, last access: 28 May 2018.

Cervantes-Escoto, F., Santoyo-Cortés, H., and Álvarez-Macías, A.: Gestión de la calidad y desarrollo desigual en la cadena de lácteos en Los Altos de Jalisco, Problemas del Desarrollo, Revista Latinoamericana de Economía, 163-187, https://doi.org/10.22201/iiec.20078951e.2001.127.7418, 2001.

Conagua: S.G.P.A./DGIRA.DDT.-1310/06, available at: http://sinat.semarnat.gob.mx/dgiraDocs/documentos/jal/ resolutivos/2006/14JA2006H0005.pdf (last access: 12 October 2020), 2006.

Conagua: Manifestación de Impacto Ambiental, modalidad regional del Proyecto: Presa El Zapotillo, para Abastecimiento de Agua Potable a Los Altos de Jalisco y a la Ciudad de León, Gto, available at: http://sinat.semarnat.gob.mx/dgiraDocs/ documentos/jal/estudios/2006/14JA2006H0005.pdf (last access: 7 September 2019), 2008.

Conagua: Sistema Nacional de Información del Agua, available at: http://sina.conagua.gob.mx/sina/tema.php?tema=cuencas (last access: 19 March 2020), 2018.

Conagua-Semarnat: Análisis espacial de las regiones más vulnerables ante las sequías en México, available at: http://www.conagua.gob.mx/CONAGUA07/Publicaciones/ Publicaciones/sequiasB.pdf (last access: 18 August 2019), 2012.

Consejo Consultivo del Agua: La Gestión del Agua en las Ciudades de México: Indicadores de Desempeño de Organismos Operadores, Consejo Consultivo del Agua, A.C., p. 34, available at: http://www.aguas.org.mx/sitio/index.php/ de-interes/publicaciones (last access: 1 November 2019), 2010. 
Cortés, S. A., Lozano, G. A., Pérez, J.: Study of Water Quality Through Hydro-Chemical Signature in León, Guanajuato, Mexico, in: Water Stress in Biological, Chemical, Pharmaceutical and Food Systems, edited by: Gutiérrez-López, G., AlamillaBeltrán, L., del Pilar Buera, M., Welti-Chanes, J., Parada-Arias, E., Barbosa-Cánovas, G., Food Engineering Series, Springer, New York, NY, https://doi.org/10.1007/978-1-4939-2578-0_51, 2015.

Crow-Miller, B., Webber, M., Molle, F.: The (Re) turn to Infrastructure for Water Management?, Water Altern., 10, 195-207, 2017.

Del Castillo, A.: León puede recuperar hasta 360 millones de $\mathrm{m}^{3}$ de sus cuencas, Milenio, available at: http://www.milenio.com/ politica/comunidad/leon-recuperar-360-millones-m3-cuencas (last access: 12 October 2020), 2018.

Delli Priscoli, J. and Wolf, A. T.: Managing and transforming water conflicts, Cambridge University Press, Cambridge, UK, 2009.

DFID: Research uptake: A guide for DFID-funded research programmes, available at: https://assets.publishing.service.gov. uk/government/uploads/system/uploads/attachment_data/file/ 514977/Research_uptake_guidance.pdf (last access: 12 October 2020), 2013.

Di Baldassarre, G., Brandimarte, L., and Beven, K.: The seventh facet of uncertainty: wrong assumptions, unknowns and surprises in the dynamics of human-water systems, Hydrolog. Sci. J., 61, 1748-1758, 2016.

DOF - Diario Oficial de la Federación: SENTENCIA dictada por la Segunda Sala de este Alto Tribunal en la Controversia Constitucional 93/2012, promovida por el Poder Legislativo del Estado de Jalisco, available at: http://www.diputados.gob.mx/ LeyesBiblio/compila/controv/166controv_11oct13.doc (last access: 8 January 2020), 2013.

DOF - Diario Oficial de la Federación: DECRETO por el que se suprimen las vedas existentes en las cuencas hidrológicas Río Tlaltenango, Río San Pedro, Presa Calles, Presa El Niágara, Presa Ajojucar, Río Encarnacioìn, Río Aguascalientes, Presa El Chique y Río Juchipila 1, Río Santiago 1, available at: http://www.dof.gob.mx/nota_detalle_popup.php? codigo $=5525352$ (last access: 8 January 2020, 2018.

Dunn, G., Brown, R. R., Bos, J. J., and Bakker, K.: The role of science-policy interface in sustainable urban water transitions: Lessons from Rotterdam, Environmental Science and Policy, 73, 71-79, https://doi.org/10.1016/j.envsci.2017.04.013, 2017.

Durand, J. and Arias, P.: Escenarios locales del colapso migratorio, Papeles de Población, 20, 9-23, 2014.

Esri: Ocean Basemap, available at: https://www.arcgis.com/home/ item.html $?$ id $=6348 \mathrm{e} 67824504 \mathrm{fc} 9 \mathrm{a} 62976434 \mathrm{bf0d} 8 \mathrm{~d} 5$ (last access: 12 February 2020), 2019.

Esteller, M. V., Rodríguez, R., Cardona, A., and Padilla-Sánchez, L.: Evaluation of hydrochemical changes due to intensive aquifer exploitation: case studies from Mexico, Environ. Monit. Assess., 184, 5725-5741, 2012.

Feldman, D. L. and Ingram, H. M.: Making Science Useful to Decision Makers: Climate Forecasts, Water Management, and Knowledge Networks, Weather Clim. Soc., 1, 9-21, https://doi.org/10.1175/2009wcas1007.1, 2009.

Fernandez, S.: Much ado about minimum flows... Unpacking indicators to reveal water politics, Geoforum, 57, 258-271, 2014.
Fisher, S., Abdi, D. I., Ludin, J., Smith, R., Williams, S., and Williams, S.: Working with conflict: skills and strategies for action, Zed books, New York, USA, 2000.

Fitch Ratings: Fitch Ratifica en "A-(mex)" al Sistema Intermunicipal de los Servicios de Agua Potable y Alcantarillado, p. 3., available at: http://www.bmv.com.mx/docs-pub/eventoca/eventoca 633934_2.pdf (last acces: 28 March 2019), 2015.

Flores-Berrones, R. F.: Acueducto Chapala-Guadalajara, Ingeniería Hidráulica En México, Enero-Abril, p. 17-28, 1987.

Flyvbjerg, B.: Survival of the unfittest: why the worst infrastructure gets built - and what we can do about it, Oxford Rev. Econ. Pol., 25, 344-367, 2009.

Frey, F. W.: The political context of conflict and cooperation over international river basins, Water Int., 18, 54-68, 1993.

Funtowicz, S. O. and Ravetz, J. R.: The worth of a songbird: ecological economics as a post-normal science, Ecol. Econ., 10, 197207, https://doi.org/10.1016/0921-8009(94)90108-2, 1994.

Gleason Espíndola, J. A., Cordova, F., and Casiano Flores, C.: The importance of urban rainwater harvesting in circular economy: the case of Guadalajara city, Management Research Review, 41, 533-553, https://doi.org/10.1108/MRR-02-2018-0064, 2018.

Godinez Madrigal, J.: Water resources model of the Verde River basin, Mexico, under different scenarios of climate change and future water demand, available at: https://github.com/ jongmadrigal/Verde-River-Basin (last access: 12 October 2020), 2019.

Godinez-Madrigal, J., Van Cauwenbergh, N., and van der Zaag, P.: Production of competing water knowledge in the face of water crises: Revisiting the IWRM success story of the Lerma-Chapala Basin, Mexico, Geoforum, 103, 3-15, https://doi.org/10.1016/j.geoforum.2019.02.002, 2019.

Gómez-Jauregui-Abdo, J. P.: Sustainable development of domestic water supply in emerging megacities: the case of the city of Guadalajara, Mexico, available at: https://opus4.kobv.de/ opus4-btu/files/3607/Gomez_Jauregui_Abdo.pdf (last access: 13 February 2019), 2015.

Gray, B.: Framing of environmental disputes, in: Making sense of intractable environmental conflicts: concepts and cases, edited by: Lewicki, R. J., Gray, B., and Elliott, M., Island Press, Washington D.C., USA, 11-34, 2003.

Gupta, J. and van der Zaag, P.: Interbasin water transfers and integrated water resources management: Where engineering, science and politics interlock, Phys. Chem. Earth, 33, 28-40, https://doi.org/10.1016/j.pce.2007.04.003, 2008.

Hernández-Antonio, A., Mahlknecht, J., Tamez-Meléndez, C., Ramos-Leal, J., Ramírez-Orozco, A., Parra, R., Ornelas-Soto, N., and Eastoe, C. J.: Groundwater flow processes and mixing in active volcanic systems: the case of Guadalajara (Mexico), Hydrol. Earth Syst. Sci., 19, 3937-3950, https://doi.org/10.5194/hess-193937-2015, 2015.

Hoekstra, A. Y., Buurman, J., and van Ginkel, K. C. H.: Urban water security: A review, Environ. Res. Lett., 13, 053002, https://doi.org/10.1088/1748-9326/aaba52, 2018.

Hommes, L. and Boelens, R.: Urbanizing rural waters: Rural-urban water transfers and the reconfiguration of hydrosocial territories in Lima, Polit. Geogr., 57, 71-80, https://doi.org/10.1016/j.polgeo.2016.12.002, 2017.

Hommes, L., Boelens, R., and Maat, H.: Contested hydrosocial territories and disputed water governance: Struggles and competing 
claims over the Ilisu Dam development in southeastern Turkey, Geoforum, 71, 9-20, 2016.

Hoogesteger, J. and Wester, P.: Regulating groundwater use: The challenges of policy implementation in Guanajuato, Central Mexico, Environmental Science Policy, 77, 107-13, 2017.

Hurtado-Jiménez, R. and Gardea-Torresdey, J.: Evaluación de la exposición a fluoruros en Los Altos de Jalisco, México, Salud Publica Mex, 47, 58-63, 2005.

Hurtado-Jiménez, R. and Gardea-Torresdey, J.: Arsenic in drinking water in the Los Altos de Jalisco region of Mexico, Revista panamericana de salud pública, 20, 236-247, https://doi.org/10.1590/S1020-49892006000900004, 2006.

Hurtado-Jiménez, R. and Gardea-Torresdey, J.: Evaluación de la exposición a selenio en Los Altos de Jalisco, México, Salud Publica Mex, 49, 312-315, 2007.

IMDEC: ¿Para quién gobierna Alfaro en Jalisco, para el pueblo o para los empresarios, IMDEC, available at: http://www.imdec. net/boletinprensaparaquiengobiernaalfaro (last access: 5 February 2020), 2019.

IMTA: Estudio Hidrológico Complementario Sobre el Aprovechamiento y Crecientes Para el Diseño de la Presa de Almacenamiento El Zapotillo, Río Verde, Jalisco, available at: http://201.131.6.193:8001/JaliscoSostenible/documentacion/\# (last access: 12 October 2020), 2005.

IMTA: Evaluación de la disponibilidad conforme a la norma NOM011-CNA-2000 para el abastecimiento de la ZCG, Informe final, Guadalajara, 2015.

Islam, S. and Susskind, L.: Using complexity science and negotiation theory to resolve boundary-crossing water issues, J. Hydrol., 562, 589-598, 2018.

Karl, H. A., Susskind, L. E., and Wallace, K. H.: A dialogue not a diatribe effective integration of science and policy through join fact finding, Environment: Science and Policy for Sustainable Development, 49, 20-34, 2007.

Krueger, T., Maynard, C., Carr, G., Bruns, A., Mueller, E. N., and Lane, S.: A transdisciplinary account of water research, Wiley Interdisciplinary Reviews: Water, 3, 369-389, 2016.

Lane, S. N., Odoni, N., Landström, C., Whatmore, S. J., Ward, N., and Bradley, S.: Doing flood risk science differently: an experiment in radical scientific method, Transactions Institute British Geographic, 36, 15-26, https://doi.org/10.1111/j.14755661.2010.00410.x, 2011.

Larsen, T. A., Hoffmann, S., Lüthi, C., Truffer, B., and Maurer, M.: Emerging solutions to the water challenges of an urbanizing world, Science, 352, 928-933, https://doi.org/10.1126/science.aad8641, 2016.

Latour, B.: Why Has Critique Run out of Steam? From Matters of Fact to Matters of Concern, Crit. Inquiry, 30, 225-248, https://doi.org/10.2307/1344358, 2004.

Lejano, R. P. and Ingram, H.: Collaborative networks and new ways of knowing, Environmental Science and Policy, 12, 653-662, https://doi.org/10.1016/j.envsci.2008.09.005, 2009.

López-Ramírez, M. E. and Ochoa-García, H.: Geopolítica del agua en la zona metropolitana de Guadalajara, Gobernanza y gestión del agua en el Occidente de México, Tlaquepaque, Mexico, 33 72, 2012.

Loucks, D. P. and Gladwell, J. S.: Sustainability Criteria for Water Resource Systems, in: UNESCO International Hydrology Series, Cambridge University Press, Cambridge, UK, 1999.
Madani, K.: Game theory and water resources, J. Hydrol., 381, $225-$ 238, 2010.

Mahlknecht, J., Hernández-Antonio, A., Eastoe, C. J., TamezMeléndez, C., Ledesma-Ruiz, R., Ramos-Leal, J. A., and Ornelas-Soto, N.: Understanding the dynamics and contamination of an urban aquifer system using groundwater age $\left({ }^{14} \mathrm{C}\right.$, ${ }^{3} \mathrm{H}$, CFCs) and chemistry, Hydrol. Process., 31, 2365-2380, https://doi.org/10.1002/hyp.11182, 2017.

Martínez, M. M., Sesma, J. S., Ojeda, W., and González, R. P.: Determinación de periodos de sequía y lluvia intensa en diferentes regiones de México ante escenarios de cambio climático, Secretaria de Medio Ambiente y Recursos Naturales (SEMARNAT), Mexico City, Mexico, 2007.

McDonald, R. I., Weber, K., Padowski, J., Flörke, M., Schneider, C., Green, P. A., Gleeson, T., Eckman, S., Lehner, B., Balk, D., and Boucher, T.: Water on an urban planet: Urbanization and the reach of urban water infrastructure, Global Environ. Chang., 27, 96-105, 2014

Melsen, L., Vos, J., and Boelens, R.: What is the role of the model in socio-hydrology? Discussion of "Prediction in a socio-hydrological world”, Hydrolog. Sci. J., 63, 1435-1443, https://doi.org/10.1080/02626667.2018.1499025, 2018.

Milman, A. and Ray, I.: Interpreting the unknown: uncertainty and the management of transboundary groundwater, Water Int., 36, 631-645, 2011.

Molle, F. and Floch, P.: Megaprojects and social and environmental changes: The case of the Thai "Water Grid", Ambio, 37, 199204, 2008.

Moore, M., Shaw, K., and Castleden, H.: "We need more data!" The politics of scientific information for water governance in the context of hydraulic fracturing, Water Altern., 11, 142-162, 2018.

Morán-Ramírez, J., Ledesma-Ruiz, R., Mahlknecht, J., and RamosLeal, J. A.: Rock-water interactions and pollution processes in the volcanic aquifer system of Guadalajara, Mexico, using inverse geochemical modeling, Appl. Geochem., 68, 79-94, https://doi.org/10.1016/j.apgeochem.2016.03.008, 2016.

Muller, M., Biswas, A., Martin-Hurtado, R., and Tortajada, C.: Built infrastructure is essential, Science, 349, 585-586, 2015.

Newig, J.: Does public participation in environmental decisions lead to improved environmental quality?: towards an analytical framework, International Journal of Sustainability Communication, 1, 51-71, 2007.

Norström, A. V., Cvitanovic, C., Löf, M. F., West, S., Wyborn, C., Balvanera, P., Bednarek, A. T., Bennett, E. M., Biggs, R., de Bremond, A. and Campbell, B. M.,: Principles for knowledge co-production in sustainability research, Nature Sustainability, 3, 182-190, https://doi.org/10.1038/s41893-019-0448-2, 2020.

Ochoa-García, H., Arrojo, P., Godinez-Madrigal, J., LópezVillegas, P., López-Aguayo, A., and Quiroz-Hernández, M.: Agua para el desarrollo regional en los Altos de Jalisco, Gestión del agua e impacto social del proyecto El Zapotillo, ITESO, Tlaquepaque, 2014.

Pacheco-Vega, R.: Conflictos intratables por el agua en México: el caso de la disputa por la presa El Zapotillo entre Guanajuato y Jalisco, Argumentos, Estudios críticos de la sociedad, 74, 221260, 2014.

Pielke, R. A.: The honest broker: making sense of science in policy and politics, Cambridge University Press, Cambridge, UK, 2007. 
Putnam, L. L. and Wondolleck, K. M.: Intractability: Definitions, Dimensions, and Distinctions, in: Making Sense of Intractable Environmental Conflicts: Concepts and Cases, edited by: Lewicki, R. J., Gray, B., and Elliot, M., Island Press, Washington, 2003.

Radio UdeG Guadalajara: Observatorio Ciudadano del Agua presentará queja ante la ONU tras resultados de la UNOPS, available at: http://udgtv.com/noticias/jalisco/guadalajarajalisco-noticias/observatorio-ciudadano-del-agua-presentaraqueja-ante-la-onu (last access: 19 April 2020), 2017.

Reed, B. G., Ortega, R. M., and Garvin, C.: Small-group theory and social work: Promoting diversity and social justice or recreating inequities?, in: Human Behavior Theory and Social Work Practice: A Diversity Framework, edited by: Greene, R. and Kropf, N., AldineTransaction, New Jersey, USA, 201-230, 2009.

Roa-García, M. C.: Equity, efficiency and sustainability in water allocation in the Andes: Trade-offs in a full world, Water Altern., 7, 298-319, 2014.

Sanz, D., Vos, J., Rambags, F., Hoogesteger, J., Cassiraga, E., and Gómez-Alday, J. J.: The social construction and consequences of groundwater modelling: insight from the Mancha Oriental aquifer, Spain, Int. J. Water Resour. D., 1-22, https://doi.org/10.1080/07900627.2018.1495619, 2019.

Sapal: Agua Potable, available at: http://www.sapal.gob.mx/ servicios/aguapotable, last access: 5 February 2020.

Schneider, A. L. and Ingram, H. M.: Policy design for democracy, University Press of Kansas, Kansas City, USA, 1997.

Siapa: Informe de Actividades Anual 2017, available at: http://www.siapa.gob.mx/sites/default/files/doctrans/informe_ de_actividades_-_anual_2017.pdf (last access: 23 July 2019), 2017.

Srinivasan, V., Sanderson, M., Garcia, M., Konar, M., Blöschl, G., and Sivapalan, M.: Moving socio-hydrologic modelling forward: unpacking hidden assumptions, values and model structure by engaging with stakeholders: reply to "What is the role of the model in socio-hydrology?", Hydrolog. Sci. J., 63, 1444-1446, 2018.

Tagle-Zamora, D., Azamar-Alonso, A., and Caldera-Ortega, A.: Cosecha de agua de lluvia como alternativa para la resiliencia hídrica en León, Guanajuato: una reflexión desde la nueva cultura del agua, Expresión Económica, 40, 5-24, 2018.

UNOPS: 1. Descripción general de la cuenca del Río Verde, available at: http://201.131.6.193:8001/JaliscoSostenible/informe/ (last access: 12 July 2020), 2017a.

UNOPS: 14. Análisis de Escenarios de Modelación, available at: http://201.131.6.193:8001/JaliscoSostenible/informe/ (last access: 12 July 2020), 2017b.

UNOPS: 12. Análisis de las demandas hídricas en la cuenca, available at: http://201.131.6.193:8001/JaliscoSostenible/informe/ (last access: 12 July 2020), 2017c.

UNOPS: 10. Análisis de datos hidrometeorológicos, available at: http://201.131.6.193:8001/JaliscoSostenible/informe/ (last access: 12 July 2020), 2017d.
Van Cauwenbergh, N: Expert and local knowledge in decision support for natural resources management: analysis of capture and use, $\mathrm{PhD}$ thesis, Department of environmental sciences and land use planning, Universite Catholique de Louvain, Belgium, 207 pp., 2008.

Van Cauwenbergh, N., Ballester Ciuró, A., and Ahlers, R.: Participatory processes and support tools for planning in complex dynamic environments: A case study on web-GIS based participatory water resources planning in Almeria, Spain, Ecol. Soc., 23, 2, https://doi.org/10.5751/ES-09987-230202, 2018.

van der Molen, F.: How knowledge enables governance: The coproduction of environmental governance capacity, Environmental Science and Policy, 87, 18-25, https://doi.org/10.1016/j.envsci.2018.05.016, 2018.

Villalobos-Aragón, A., Ellis, A. S., Armienta, M. A., MortonBermea, O., and Johnson, T. M.: Geochemistry and Cr stable isotopes of Cr-contaminated groundwater in León valley, Guanajuato, México', Appl. Geochem., 27, 1783-1794. https://doi.org/10.1016/j.apgeochem.2012.02.013, 2012.

Vishwakarma, B. D., Devaraju, B., and Sneeuw, N.: What Is the Spatial Resolution of grace Satellite Products for Hydrology?, Remote Sensing, 10, 852, https://doi.org/10.3390/rs10060852, 2018.

Voinov, A. and Gaddis, E. J. B.: Lessons for successful participatory watershed modeling: A perspective from modeling practitioners, Ecol. Model., 216, 197-207, https://doi.org/10.1016/j.ecolmodel.2008.03.010, 2008.

Von Bertrab, E.: Guadalajara's water crisis and the fate of Lake Chapala: A reflection of poor water management in Mexico, Environ. Urban., 15, 127-140, 2003.

WATTAgNet: Who are the world's largest egg producers, available at: https://www.wattagnet.com/articles/ 20682-who-are-the-world-s-largest-egg-producers (last access: 4 June 2018), 2015.

Wesselink, A., Buchanan, K. S., Georgiadou, Y., and Turnhout, E.: Technical knowledge, discursive spaces and politics at the science-policy interface, Environmental Science and Policy, 30, 1-9, https://doi.org/10.1016/j.envsci.2012.12.008, 2013.

Whatmore, S. J.: Mapping knowledge controversies: Science, democracy and the redistribution of expertise', Prog. Hum. Geog., 33, 587-598, https://doi.org/10.1177/0309132509339841, 2009.

Zevenbergen, C., Veerbeek, W., Gersonius, B., and Van Herk, S.: Challenges in urban flood management: travelling across spatial and temporal scales, J. Flood Risk Manag., 1, 81-88, 2008.

Zimmerer, K. S.: Spatial-geographic models of water scarcity and supply in irrigation engineering and management: Bolivia, 19522009, in: Knowing Nature: Conversations at the Intersection of Political Ecology and Science Studies, edited by: Goldman, M. J., Nadasdy, P., and Turner, M. D., The University of Chicago Press, Chicago, IL, 167-185, 2008. 